\title{
КОНЦЕПЦИИ И ПРИНЦИПЫ ОРГАНИЗАЦИИ ИНВЕСТИЦИЙ В РЕАЛЬНЫЙ СЕКТОР ЭКОНОМИКИ
}

\author{
(c) 2021 Саламов Фаррух Фаттоевич \\ аспирант кафедры теоретической экономики \\ Самарский государственный экономический университет, Россия, Самара \\ E-mail: farrux_sies@mail.ru
}

В данной статье рассматривается методологическое значение категорий «концепция» и «принципы» применительно к организации процесса инвестирования в реальный сектор экономики. Автор систематизирует содержание и эволюцию взглядов представителей различных экономических школ на процесс инвестирования реального сектора экономики в концептуальном и принципиальном аспектах. Ввиду дискуссионности рассматриваемой проблемы обосновывается авторская трактовка категорий «концепция» и «принцип» применительно к процессу инвестирования.

Определение концептуальных положений, описывающих движение инвестиций в реальном секторе экономики, требует предварительного исследования сущности понятия «концепция». Термин «концепция» происходит от латинского слова «соnceptio», что означает «схватывать», и зародился в рамках развития средневекового философского течения концептуализма, представителями которой были такие известные мыслители, как Пьер Абеляр, Иоанн Дунс Скот и другие. Основателем концептуализма, среди упомянутых философов, считается П.Абеляр, который впервые сформировал основные идеи концептуализма и определил его принципы, как специфического синтеза рационализма и эмпиризма. Взгляды П.Абеляра были присущи работам его последователей, которые были представителями различных течений и разных эпох. Так, некоторые положения средневекового концептуализма были характерны для философских идей Дж. Локка и Г. Гегеля. Определенные черты основанной П.Абеляром философского течения, были свойственны также для таких известных мыслителей, как Аристотель, Фома Аквинский, Уильям Оккам и другие [1, с. 33-34].

Сущность концептуализма П. Абеляра заключалась в том, что общие понятия не являются ни реальностью, ни обозначением содержания слов, они присущи уму человека до начала познания и приобретают определенное значение через опыт человека [2].

Продолжателем традиций концептуализма стал знаменитый шотландский философ, автор труда «Исследование человеческого ума на принципах здравого смысла», Гамильтон. Будучи представителем школы британского эм- пиризма, указанный философ не изменял традициям Шотландии и поэтому сумел развить концептуализм в качественно новую форму. Так, В.Гамильтон пользуясь термином «концепт» толковал сущность концепций, как форм, которые восстанавливают целостность перцептивного опыта, однако отличаются от перцепции концентрацией внимания [3].

B XX в. главным признаком концепции считалась символизация личного перцептивного опыта через воображение. Впервые такие мысли проявили себя в работах американского философа С. Лангер, которая прославилась своими трудами в области эстетики и сознания и осуществила весомый вклад в понимание сущности «символа» в науке. Другими учеными, которые осуществили значительный вклад в исследование указанной проблематики в XX веке, были Е.Кассирер и А.Уайтхед, ученицей которых и была С. Лангер.

Следует также отметить толкование роли концепции в науке такими философами, как Ж.Делёз и Ф.Гваттари, известных своими работами «Что такое философия» и «Анти-Эдип: капитализм и шизофрения», в которых авторы применяют понятие концептов, ключевой особенностью которых было то, что они сформировали ядро любой концепции, и трактуют ее как нечто присущее мысли, самой ее возможности, как живую категорию или элемент трансцендентального опыта $[4,5]$.

Поскольку концептуализм пытался решить чрезвычайно общую и важную для философии проблему иерархии важности разума и чувств в познании человеком мира, то необходимо отметить, что свой вклад в развитие концептуализ- 
ма совершили очень много мыслителей. Однако особенно весомыми и имеющими отношение к исследуемой научной проблеме являются работы Д.Серля, Ю.Хабермаса, Б.Вальденфельса, Н.М.Бахтина, К.А.Апеля, В.С.Библера, Х.Блюменберга и тому подобные.

На основе мнений известных ученых можно сказать, что под концепцией следует рассматривать предельно обобщенный взгляд на сущность определенного явления, на базе которого возможно построить общую теоретическую основу для толкования и решения определенных исследуемых проблем.

Учитывая приведенную точку зрения, следует отметить, что важной составляющей любой концепции могут быть принципы, поскольку они строятся путем индуктивного перехода от детального к общему. Происхождение понятия термина «принцип» связывают с латинским словом «principium», что переводится как начало, первооснова. Поэтому можно отметить, что наличие принципов следует считать одной из базовых требований формирования любой теории, в том числе экономической. Значимость принципов в науке умело подчеркивал академик А.И.Берг, который по данному поводу высказывался следующим образом: «без принципов человек подобен кораблю без руля и компаса». В силу сказанного, предположение Н.Г. Чернышевского, о том, что отсутствие четких принципов неизбежно приводит к путанице можно считать вполне справедливым. Важность принципов для науки также доказывал Т. Пэйн, один из авторов конституции США, который утверждал, что армия принципов проверяется там, где не пройдет армия солдат. Следуя за базовыми понятиями о принципах, С.Г.Дробязко, сделал вполне справедливый итог, о том, что принципы характерны абсолютно всем явлениям и процессам [6, с. 27].

Учение о принципах функционирования экономики развивалось параллельно развитию научных идей и взглядов известных ученых экономистов, начиная с фундаментальных работ Г.Кантильона, Ф.Кенэ, А.Смита, Д.Рикардо и заканчивая современными учеными К.Г. Макконелом, С. Г.Брю, Н. Г. Мэнкью и другими.

Одними из первых ученых, чьи труды можно рассматривать, как такие, которые сформированы на базе четкого набора принципов, были представители течения физиократов. Ключевыми для данного течения считаются труды
Г. Кантильона и Ф.Кенэ. Данные исследователи видели причины богатства в свойствах факторов производства, в частности, в земле. Однако данные научные взгляды не нашли широкого распространения в последующих поколениях ученых.

Известный основоположник экономической теории, автор труда «Исследования природы и причин богатства народов», Адам Смит принципиальной причиной формирования богатства наций рассматривает именно труд. Данный тезис противоречил воззрениям физиократов о том, что земля является главным условием успешности народов. А. Смит строил свои научные доводы на базе предположения, что уровень богатства нации меняется без смены климата и качеств земельных ресурсов. На основе данных идей упомянутый ученый сформировал одну из первых систем принципов функционирования экономики: труд главный фактор богатства наций; стоимость товара формируется из двух составляющих: стоимости обмена, стоимости потребления; стоимость факторов производства определяется доходом от их использования; отсутствие вмешательства в рынок со стороны государства является необходимым условием обеспечения развития последнего [7].

Другой известный представитель британской школы экономистов Д.Рикардо построил свою экономическую теорию на базе подобных Смиту принципов, выступив сторонником его идеи о невмешательстве государства в функционирование рынка. Параллельно со сказанным, Д.Рикардо также убеждал, что главная цель политической экономии - определить законы распределения доходов, на основе чего им была разработана концепция о «миграции» капитала между различными рынками.

Работы упомянутых ученых были крайне важными для дальнейшего развития научной экономической точки зрения. Так, на базе сформированных А. Смитом и Д. Рикардо принципов были разработаны экономические теории, связанные именно с рыночными механизмами наращивания капитала и формирования его стоимости. Следовательно, наследниками «великих британцев» стали не менее знаменитые ученые Д.Милль, Т.Мальтус, А.Маршал, К.Виксель и много других.

Другим известным ученым, который построил обширную теорию на базе сформированных им экономических принципов, может считаться 
К. Менгер (1840-1921), основатель австрийской школы экономистов, автор многих ключевых работ, посвященных не только политической экономике, но и политологии. Самой весомой работой ученого стала, опубликованная в 1871 г. работа под названием «Основы политической экономии» (Grundsatze der Volkswirtschaftslehre), оказавшая значительное влияние на дальнейшее развитие экономической теории во все последующие периоды ее эволюции. Значимость данной работы трудно переоценить. Другой известный представитель австрийской школы, Ф.А.Хайек, комментирует данную работу как одну из наиболее важных в экономической теории, сравнивает еe с «Principles» Д. Рикардо [8]. Главная идея «Grundsatze» заключалась в формировании единого принципа функционирования экономики, определенного на основе определенной всеобъемлющей идеи. С этой целью К. Менгер делает попытку критики некоторых идей А. Смита. Так, австрийский экономист предлагает свой способ решения «проблемы Смита» связанной с разницей в стоимости алмазов и воды. В частности, К. Менгер для поиска ответа на данный вопрос вводит новое понятие: «субъективной стоимости», которое трактуется в его «Grundsatze», как следствие присущей некоторым ресурсам «относительной редкости». Выстроенная на базе упомянутых понятий теория формирует новое представление о ценообразовании на рынке.

Дальнейшее развитие данная концепция получила в сформированном К. Менгером принципе комплементарности производственных благ. Базовой идеей в данном вопросе было то, что ценность производственных благ также рассматривалась, как «относительная» и зависит от «укомплектованности» последних. Следует отметить, что доминирование принципов «относительности» и «укомплектованности» в научных теориях К. Менгер могло быть обусловлено значительным усложнением производственных процессов, что имело место во времена, когда творил упомянутый ученый.

Научные идеи, сформированные в «Grundsatze» получили широкое распространение в трудах известных ученых следующих поколений. Следовательно, базовые принципы К.Менгер характерные для взглядов А.Маршала, выражены им в своей работе «Принципы политической экономики» [86]. Другие известные ученые Смарт и Дж.Бонар активно распространяли идеи «Grundsatze» в англоязычном мире [9, c. 32]. Кроме высказанных выше идей К. Менгер также прославился своим спором с представителем так называемой новой экономической школы Г.Шмоллером (1838-1917). Предметом спора выступил метод экономики, а точнее принципы его построения. Следовательно, К. Менгер убеждал, что метод экономики должен базироваться на упрощении процессов, которые имеют место в рамках ведения народного хозяйства. Это очевидно было обусловлено тем, что как уже отмечалось, упомянутый ученый своей целью считал сформировать всеобъемлющую идею на основе которой могла бы базироваться вся экономическая теория.

Г.Шмоллер убеждал, что источником экономического знания следует рассматривать эмпирические наблюдение и путем индуктивных выводов на их основе определять институциональные особенности динамики процессов в экономике.

Однако толкование сущности понятия «экономический принцип» осталось вне поля зрения упомянутых ученых. Внимание на это обратили ученые современности. Так, К. Г. Макконнелл и С.Г.Брю утверждают, что экономический принцип - это обобщение, которому присущи некоторые количественные неточности. Указанные ученые в своих выводах опираются на предположение, что определение принципа возможно только путем индукции, умозаключения, на базе которой всегда будут иметь место исключения. Отсюда и абстрактный характер любых экономических принципов [10].

К другим ученых, которые осуществили значительный вклад в определение принципов экономики, можно отнести Н.Г.Мэнкью, который описал десять принципов на которых базируются знания об экономике. Так, указанный ученый приводит 10 принципов экономики [11, с. 30-40]:

- ориентация на клиента;

- стоимость продукта - это стоимость того, от чего нужно отказаться, чтобы получить этот продукт;

- рациональный человек мыслит в терминах предельных изменений;

- человек реагирует на стимулы;

- торговля носит взаимовыгодный характер;

- рынок - прекрасный способ организации экономической деятельности;

- иногда необходимым является вмешательство государства в экономику; 
- уровень жизни населения определяется способностью государства производить товары и услуги;

- темпы роста цен на продукцию зависят от темпов роста денежной массы в экономике;

- в краткосрочной перспективе общество должно делать выбор между безработицей и инфляцией.
Таким образом, приведенные указанным ученым принципы отражают общие особенности функционирования рыночной экономики. Эти принципы можно рассматривать как «стартовую точку» для обоснования разного рода явлений, которые имеют место в экономике, в том числе - инвестиций в ее реальный сектор.

\section{Библиографический список}

1. Степанищев А.Ф. Рациональность философии и науки: от классики к постнеклассике: монография/ А. Ф. Степанищев. - Брянск: БГТУ, 2006.-С. 236

2. Абеляр, П. Теологические трактаты: [пер. с лат.] / П.Абеляр; вступ. ст., сост. С. С. Неретиной.- М.: Прогресс, Гнозис, 1995.- С. 413.

3. Пассмор Дж. Сто лет философии: Пер. с англ.-М.: «ПрогрессТрадиция», 1998.- С. 496

4. Делёз Ж., Гваттари Ф. Что такое философия? / Пер. с фр. И послесл. С. Н. Зенкина.- М.: Институт экспериментальной социологии, Спб.: Алетейя, 1998.-С. 288..

5. Делёз, Ж., Гваттари, Ф. Анти-Эдип: Капитализм и шизофрения - Екатеринбург: У-Фактория, 2007.-С. 672.

6. Дробязко С.Г. Принципы в праве / С.Г.Дробязко // Проблемы развития юр. науки и совершенствование правопр. практики: сб. науч. тр.- Минск: БГУ, 2005.-С. 27-33.

7. Аникин А. В. Шотландский мудрец: Адам Смит // Исследование о природе и причинах богатства народов.М.: Эксмо, 2007.- С. 879-901.

8. Макконнелл К.Р. Экономикс: принципы, проблемы и политика / К. Р. Макконнелл, С.Л.Брю; Пер. с 13-го англ. изд.- М.: ИНФРА-М, 1999, XXXIV.-С. 4-5.

9. Черненький В.П. Экономическое развитие предприятия: сущность и виды / В. П. черненький // Формирование рыночной экономики: наук. сб. / Министерство образования и науки; отв. ред. А.А. Беляев. - 2010.Вып. 23.- С. 116-126.

10. Макконнелл К.Р. Экономикс: принципы, проблемы и политика / К. Р. Макконнелл, С.Л.Брю; Пер. с 13-го англ. изд.- М.: ИНФРА-М, 1999, XXXIV.-С. 4-5.

11. Мэнкью Н.Г. Принципы экономикс.-СПб: Питер Ком, 1999.- С. 784. 